\title{
Unge innvandrermenn, kriminalitet og kjønnskultur
}

På kjønnets omraide er det store forskjeller mellom den rent norske befolkningen og innvandreve. Denne artikkelen stiller spørsmailet om slike forskjeller kan ses $i$ sammenbeng med den kriminalitet noen unge innvandrermenn begair?
I

mars 1998

ble jeg invitert av Nettverket for mannsforskning i Norge til å holde et innlegg over tittelen «Maskulinitet og marginalisering blant unge innvandrere» på et seminar om «maskuline subkulturer». Seminaret var knapt annonsert før jeg hadde avisen Verdens Gang på tråden, det norske svaret på Ekstra bladet, journalisten mente dette kunne egne seg som påskestoff. Jeg forsto henne godt, men avslo å la meg intervjue. Det er noe litt pikant, men også litt lummert over dette temaet. Det er en gylden anledning til å gi ulike fordommer, særlig om muslimske menn, en intellektuell innpakkning og en legitimering gjennom forskning. Under temaet anes en undertone av samme holdning som for noen år siden førte til forslag om at alle innvandrermenn skulle sendes på kjønnskurs når de kom til Norge, for å lære å forstå norske kvinners signaler, at miniskjørt ikke nødvendigvis er en seksuell invitt og at et nei betyr nei. Forslaget ble oppfattet som svært sårende av 
mange innvandrere. Tanken om at innvandrermenn skal ha en annen «kjønnskultur» enn norske menn er høyst problematisk, samtidig som det er åpenbart at en del av de forskjeller som finnes mellom kulturer nettopp vedrører kjønn. Temaet for denne artikkelen er i hvilken forstand en eventuelt kan snakke om at det er forskjeller på dette området, og hvilke konsekvenser slike forskjeller eventuelt kan ha for sosial integrasjon av unge menn med innvandrerbakgrunn.

Jeg skal starte med å kile fordommene litt, med en historie som kan få nordiske lesere til å tenke at «akkurat sånn er de». Det gjelder Aman, en 20 år gammel gutt fra en flyktningefamilie med mange barn, i en drabantby. Faren er svært religiøs og har forsøkt å gi barna en streng oppdragelse. Han har stort sett vært arbeidsløs siden han kom til Norge, for ifølge Aman klarer han ikke å arbeide for andre, ettersom han alltid har drevet selvstendig, og dessuten synes han nå at det er de eldste sønnenes tur til å forsørge familien. Ettersom en av eldste sitter $\mathrm{i}$ fengsel, en har stiftet egen familie og en går på skole, betyr det at det stort sett er sosialkontoret som betaler. De yngre barna er tidvis under barnevernet.

For Aman gikk det galt helt fra han kom til Norge, 11 år gammel. Han sloss hele tiden på skolen, og mener det var fordi han ikke forsto norsk at det skjedde. Så måtte han gå på spesialskoler, ble byvanker (betegnelse på ungdom som oppholder seg mye ute i byens sentrum), var under Barnevernets omsorg en tid, brukte narkotika, og sonet en nokså lang fengselsstraff. Han forteller at han begikk mange ran som tenåring, og sier en grunn var at han ikke fikk noen penger hjemme. Men han sier likevel at han ville nok ha slått ned folk uansett, for det var tøft, spennende, kult. Det handlet om å vise seg for vennene, og å vise seg for jenter. Når politiet kom inn i bildet, sa de at de hadde slått ned folk som kalte dem svartinger. Men det var som regel ikke sant, for de som kalte dem for det, anmeldte al- dri. Han sier han er ferdig med denne volden nå, men etter intervjuet skulle han likevel ut for å ta en som hadde gjort noe mot en kamerat av seg: "Ingen skal røre vennene mine». Det handlet om å sette seg i respekt og å beskytte sin xre. Han hadde fått en varig skade i et tidligere slagsmål, hvor det var en yngre brors ære han skulle forsvare.

Kvinnesynet hans er ikke helt på linje med rådende idealer $\mathrm{i}$ Norge. Han fortalte at da han fikk en kjæreste, var hun den første norske jenta han tiltalte med navn, før hadde han bare sagt: «Hore, kom hit!». Men kjæresten hadde ikke ventet på ham de månedene han satt $\mathrm{i}$ fengsel. Etter det hadde ingen $\mathrm{i}$ gjengen villet hilse på henne. I Norge er det to ting en ikke kan stole på, pleide gutta i gjengen å si, det var det norske været og de norske jentene. Derfor er det så mange skilsmisser i Norge, mener Aman. Han vil heller gifte seg med en kvinne fra hjemlandet, for han vil ikke være sammen med en som drikker, går på diskotek, går med miniskjørt og bikini på stranda, slik han sier norske jenter gjør. Som han sier: "Hvorfor skal jeg la kona mi vise kroppen sin til andre folk?»

En tolkning av denne historien kan være at hans mannlighetsidealer, knyttet til ære og respekt, med høy grad av aksept for aggressiv atferd, bidrar til å sette ham på kant med det norske samfunnet. Amans far er et dårlig rolleforbilde, han innfrir verken sin egen kulturs og norske mannlighetsidealer: Han er fattig, ikke selvforsørgende, han klarer ikke å holde orden på barna sine og har liten respekt i det norske samfunnet. Han er $\mathrm{i}$ en like marginalisert posisjon som sønnen er. Med sin nedlatende holdning til norske jenter er det lite sannsynlig at Aman vil komme til å etablere et godt familieliv med en norsk jente, noe han heller ikke ønsker. Men med sin kriminelle fortid, løse arbeidstilknytning og problemfylte familie er han ingen drømmekandidat på sitt opprinnelseslands ekteskapsmarked heller. Ifølge en slik lesning er det altså en kulturell sære- 
genhet som bringer ham på kant med det norske samfunnet.

Men i så fall bør det legges til at det ikke er ved å legge av seg det kulturelt spesifikke og ved å ta til seg det norske at Aman i dag ser ut til å havne på rett kjøl igjen. I fengselet leste han Koranen, bestemte seg for å forsøke å kutte ut stoffmisbruket og forsøke å ta seg av sin familie. Han synes han skylder dem mye, og sier om sin far: «Når han begynte å jobbe i [opprinnelseslandet], hvem var det han jobba for? Familien sin. Alene. Han tok oss hit med egne penger. Vi betalte jo null penger. Han har slitt mye. Pluss at han har slitt mye her i Norge. De har levd sånn at barna deres bare ble kriminelle alle sammen. Det er ikke lett for dem å vise ansiktet til andre folk når det skjer sånn.» Nå er det Amans tur til å ta seg av foreldrene. En sosialarbeider hjalp ham til å få en praksisplass, og deretter har han fått seg en alminnelig jobb. Det dreier seg om ufaglært arbeid til en lav lønn, men han skjøtter sitt arbeid og har allerede fătt forfremmelse til en noe mer ansvarsfylt posisjon. Om "kultur" kan forklare hans marginalisering, ser det ut som om "kultur” også kan forklare hans reintegrasjon.

For om det er noen sammenheng mellom kultur, kjønn og marginaliserthet, er den nok av en ganske kompleks karakter, og spørsmålet egner seg derfor neppe særlig godt som påskestoff i Verdens Gang. Jeg vil i denne artikkelen se om det kan være noen sammenheng mellom kriminalitet og kjønnskultur for unge menn med bakgrunn fra land utenfor Europa og Nord-Amerika. Med kjønnskultur forstås holdninger, verdier, stil og praksisformer knyttet til maskulinitet og feminitet. Jeg vil presisere at det ikke ligger noen antakelse om at unge menn med innvandrerbakgrunn er mer kriminelle enn de uten er, her ser jeg bare på om den kriminalitet de står bak kan ha sammenheng med kjønnskultur

Min bakgrunn for å uttale meg om dette er et pågående forskningsprosjekt hvor jeg studerer integrasjon, isolasjon og marginali- sering blant unge innvandrere. Det vil si at informantene i hovedsak er mellom 20 og 25 år gamle og i hovedsak har foreldre fra Pakistan, Tyrkia og Vietnam, men her er også informanter fra Afrika, Latin-Amerika og andre land i Asia. De fleste har det meste av oppveksten fra Norge. Jeg har selv intervjuet 39 personer, av begge kjønn og i alle slags ulike livssituasjoner, det vil si studenter, yrkesaktive, arbeidsløse, fengselsinnsatte og hjemmeværende mødre. I tillegg disponerer jeg intervjuer Viggo Vestel har foretatt med 15 drabantbygutter med samme type innvandrerbakgrunn, altså i alt 54 informanter. Prosjektet mitt handler ikke spesielt om mannlighetskulturer og kriminalitet, men prosjektets innretting har sikret at unge menn som kommer fra drabantbyer eller indre bystrøk og som har erfaring med rusmidler, kriminalitet eller andre former for sosial marginalisering, er godt representert.

\section{OM KULTURFORKLARINGER OG KJØNNSKULTURER}

Mitt materiale er rent kvalitativt, og utfra det kan jeg ikke uttale meg om hvorvidt det er en generell sammenheng mellom innvandringsbakgrunn og kriminalitet. Det jeg studerer er de individuelle prosessene som i noen tilfeller har ledet fram til kriminalitet, og det jeg da kan si noe om, er hvorvidt det $\mathrm{i}$ de historiene er en sammenheng mellom innvandringsbakgrunnen og kriminaliteten eller ikke. I flere tilfeller ser jeg at det ikke er noen slik sammenheng, men at kriminaliteten snarere har de samme årsaker som for norsk ungdom som blir kriminelle, for eksempel store familieproblemer i barndommen. I andre tilfeller ser jeg en sammenheng, men på høyst ulike måter. Det kan handle om diskriminering, og det kan handle om sosial klasse og utsatte bomiljøer. Og det kan handle om kultur. I mitt arbeid har jeg ønsket å se hvor langt jeg kommer med andre forklaringer før jeg bruker kultur som forklaring. Det skyldes at 
når det gjelder forskning om innvandrere, ligger forestillingen om «kultur» og alt som kan forklares med «kultur» som et tungt, vått teppe over hele feltet. Jeg har derfor sett etter andre forklaringer, og jeg har forsøkt å frigjøre meg fra kulturforståelsen ved å sette sammen et utvalg på tvers av nasjonaliteter, for å gjøre fristelsen til å bruke kultur som forklaring noe mindre.

Problemet med kulturforklaringer er for det første risikoen for en generalisering, som fremstiller da det «pakistanske» eller det «norske» som noe enhetlig, og overser at variasjonen innad kan være langt større enn variasjonen mellom. Det er for det andre risikoen for en essensialisering, prinsipielt av samme art som en raseforklaring: En person er slik og slik fordi han eller hun er pakistansk. Det er for det tredje risikoen for en statisk forståelse, av at det vi beskriver evig og uforanderlig vil være slik. Og det er for det fjerde risikoen for at en ved å fokusere på kultur overser viktigere forklaringer, og slik jeg ser det, først og fremst mer strukturelle forklaringer og forhold som har med makt og dominans å gjøre.

Men samtidig blir en fullstendig avvisning av kulturforklaringer helt usosiologisk, det vil innebære å avvise læring og pregning, avvise sosialisering. Det vi trenger er mer dynamiske begreper, som fanger variasjon, dynamikk og endringspotensialer. Jeg ser for eksempel begrepet habitus som et slikt begrep (om begrepet, se f.eks. Bourdieu og Wacquant 1993). Det fanger læring, i form av en dyptgående og kroppsliggjort pregning, hele ens væremåte reflekterer en inkorporering av den sosiale verdens strukturer som så er blitt ens egne mentale strukturer, og slik strukturerer oppfattelsen av verden og ens reaksjonsmønster i forhold til det. Men det handler om en sammensatt pregning, hvor en rekke trekk ved ens sosiale situasjon spiller inn, slik at det ikke gir noen mening å snakke om «en tyrkisk habitus». Tyrkiske habitusformer vil variere med kulturell og økonomisk kapital i hjemmet, med bakgrunn fra by eller land, med særtrekk ved oppvekststed samt en rekke mer idiosynkratiske faktorer. Videre betegner en habitus ikke noe fastlåst i et menneske, men snarere det trege, det som gjør oss rimelig forutsigelige for våre nærmeste, som vet hvordan vi vil reagere på dette eller hint. Settes vi i en helt annen sosial kontekst, hvor våre mentale strukturer ikke lenger svarer til de strukturer som omgir oss, innebærer det en utfordring, og ofte en kilde til lidelse eller til forandring (jfr. Bourdieu 1997 s. 190, samt eksempler i intervjuer med eldre innvandrere i Bourdieu et.al. 1993). Og det er akkurat det som har skjedd med mange i foreldregenerasjonen av innvandrere. De kan forsøke å skape avgrensede, sosiale rom hvor de sosiale strukturene som omgir dem kan forbli i samsvar med deres mentale strukturer. Men de kan ikke lenger ta denne oppfattelsen av verden for gitt. Og barna må nødvendigvis leve i ulike sosiale kontekster, og med det utvikle mer kompliserte habitusformer, hvor pregningen fra alle disse kontekstene setter sine spor.

Et eksempel på denne sammensatte pregningen kan være Mustaffa, en tyrkisknorsk gutt som kommer fra en drabantby. Han skeier gradvis ut sammen med en gjeng og opplever så at det er svært vanskelig å komme på rett kjøl igjen, blant annet på grunn av det han opplever som en trakassering fra politiets side, i form av hyppige kontroller når han er ute og kjører, og hjemmebesøk. En gang hadde politiet fulgt etter ham og ventet til et innbrudd var $\mathrm{i}$ gang før han ble pågrepet. Han forteller også at politiet en gang tok kontakt med hans arbeidsgiver for å fortelle at han var tidligere straffet, med den følge at han mistet jobben. Men det er andre forhold som også gjør det vanskelig for ham. Han snakker i og for seg flytende norsk uten egentlig aksent, men han gjør noen språkfeil, på tross av at han har bodd i Norge siden han var 9 år gammel. Jeg kan ikke vurdere ham utfra klærne, ettersom jeg traff ham i fengselsantrekk. Men utseende sier likevel mye 
- selvsagt mørkt hår og hud, i tillegg en hårklipp som har et klassestempel, skuldre som vitner om mye styrketrening og en macho-måte å bevege seg på. Alt i alt innebærer dette en form for sosialt stigma. Men denne habitusformen er preget av veldig mye mer enn det at hans foreldre er fra Tyrkia. Her er spor etter den norske drabantbyen, etter en mangelfull skolegang og også etter noen år i fengsel. Hjemme i landsbyen vil han kanskje bli oppfattet som norsk. Jeg vet ikke mye om hans far, men ut fra hva Mustaffa forteller, er han veltilpasset i det norske samfunnet. Mustaffa har norsk kjæreste, men har bevart mange av de tradisjonelle, tyrkiske holdningene på kjønnets område, og sier for eksempel om sin søsters oppvekst: «Jeg visste jo alltid hva hun holdt på med og sånn. Men hun har ikke vært den typen som har gått ut på byen for å feste og ha det moro og sånn. Jeg må si hun har vært meget dyktig og holdt seg hjemme hele tida og gjort stort sett skolearbeid og det som skal til hjemme, å lage mat og alt mulig sånt. (Hvis hun hadde vært mye ute og festet, så ville det vært vanskelig, eller?) Ja, fra min side i hvert fall. For jeg veit jo sånn noenlunde hvordan den norske ungdommen fester og har det moro og sånn, og der går det jo over stokk og stein. Så der har hun hatt et meget godt liv.». Hans sosiale marginalisering kan settes i sammenheng med hans måte å være mann på, men en kan ikke si at denne måten å være mann på er utpreget tyrkisk. Den inneholder en rekke elementer, noe norsk og noe tyrkisk, og mye henger sammen med drabantbyen og noe med fengselskulturen. Og ikke rent lite kan vel skrives på en arbeiderklassekultur, som er på vikende front $\mathrm{i}$ hele den industrialiserte verden.

Her er vi ved en av de nevnte grunnene til skepsis overfor kulturforklaringer: det feilaktige i å omtale «det norske» som noe enhetlig. «Det norske» gjennomskjæres av mange og kryssende motsetningslinjer. En av dem er klasse, og maskulinitet finner ulike uttrykk i ulike klasser. Om dette har
Bourdieu og forskere som arbeider i hans tradisjon skrevet en god del (se Prieur 1998). I Distinksjonen (Bourdieu 1995) er det flere eksempler som viser at arbeiderklassens menn ser seg selv som de mest maskuline, de sterkeste, de mest virile. Fysisk styrke ses som en alternativ kilde til selvfølelse for de som har lite økonomisk eller kulturell kapital, og er en grunnleggende dimensjon ved manndom. Bourdieu setter dette i sammenheng med at bønder og arbeidere i langt sterkere grad enn noen annen klasse er avhengige av sin muskelkraft.

Denne vekten på kroppslig kapital er noe vi forbinder med flere maskuline subkulturer som har det til felles at de kan knyttes til lavere klasser. I sin artikkel om franske loubards (1983) tar Gérard Mauger og Claude Fossé-Poliak, som også arbeider i Bourdieu-tradisjonen, utgangspunkt $i$ at disse unge drabantbyguttene med spisse støvler og skinnjakker og en røff livsstil gjennom det viser sin maskulinitet. Uten kulturell eller økonomisk kapital er det den kroppslige kapitalen som er deres styrke, eller deres kilde til verdighet. De kler seg og beveger seg som cowboys, de tatoverer seg, de snakker slang, de drikker hardt, de slåss, de er småkriminelle, de liker hardrock, fotball og motorsykler. Gjennom dette uttrykkes, som Bourdieu skriver, en «mannskroppens praktiske filosofi hvor den framstår som en slags stor og sterk kraft, med enorme, bydende og brutale behov» (1979: 211).

En annen slik subkultur er blitt studert av Loïc Wacquant (1992, 1995), nemlig svarte boksere i Chicago. Han viser den tette sammenhengen mellom en bestemt posisjon i det sosiale rommet og en maskulinitetsform. Det tradisjonelle bildet av bokseren er fattiggutten som ikke har andre karriereveier. Men Wacquant viser at dette bildet er altfor unyansert. Vel bærer bokserne ofte på en drøm om å oppnå rikdom gjennom boksingen, men om det bare var drømmen om rikdom som betydde noe, ville både lagidretter og kriminalitet gi høyere sjanse for suksess. Og de kommer ikke fra 
Foto: Mikkel Ostergaard/Billedhuset. 
de aller fattigste segmentene av de laveste klassene (1992: 232-33). De aktive bokserne $\mathrm{i}$ hans studie hadde noe høyere utdanning og noe høyere sannsynlighet for å være gift og ha en jobb, en bil og en bankkonto enn hva som var vanlig blant unge menn i dette strøket. Den harde treningen krever en viss stabilitet i livet, og en god porsjon disiplin og offervilje. De som kommer fra de mer etablerte segmentene av arbeiderklassen er derfor de beste rekruttene. Wacquant (1995: 67) viser hvordan bokseren bygger opp og pleier en kroppslig kapital. Kroppen er på en og samme tid hans produksjonsmiddel, det råmaterialet han og hans trener og manager arbeider med og på, og langt på vei også produktet av hans tidligere trening og livsførsel. På denne måten er kroppslig kapital og kroppsarbeid tett forbundet med hverandre. Behandlet riktig vil kroppen hans være i stand til å produsere mer verdi enn det som er blitt investert i den. Men målet med investeringene er slett ikke bare økonomisk vinning. Kroppen inngår $\mathrm{i}$ en form for impression management, hvor en veltrent og stor kropp er egnet til å skremme motstanderne. Men det estetiske er også et mål i seg selv: En slik kropp oppleves som vakker. De kroppslige investeringene inngår også i et helt verdighetsprosjekt: En vellykket bokser viser at han har både fysisk og psykisk styrke, sterk selvdisiplin med hensyn til trening og til å tåle smerte, og med hensyn til matinntak, men, og kanskje mer overraskende, også med hensyn til vold og til sex. Han skal være i stand til å unngå å la seg provosere, og han skal klare seksuell avholdenhet i lengre perioder, da bokserne tror at sex gjør en mann myk og svak. Slik konstruerer altså bokserne sin særegne maskulinitetsform utfra en kroppslig kapital, og utfra de muligheter og begrensninger deres posisjon i det sosiale rommet gir dem.

Bevæpnet med en slik mer spesifisert og nyansert anvendelse av kultur som forklaringsfaktor kan vi gå tilbake til innvandrergutte- ne i Norge og spørre om det gir mening å si at de har en spesiell kjønnskultur.

\section{HAR UNGE INNVANDRERMENN EN SPESIELL KJØNNSKULTUR?}

Når det gjelder holdninger på kjønnets område, viser en undersøkelse fra Oslo ( Øia 1998) at unge med innvandrerbakgrunn har noe mer tradisjonelle holdninger enn unge uten, og gutter har mer tradisjonelle holdninger enn jenter. Men også blant unge med innvandrerbakgrunn er langt de fleste enige i uttalelser som at «jenter som har fylt 16 år, bør selv få bestemme når og med hvilke gutter de vil gå ut», «kvinner og menn bør ha like stor innflytelse på politikk og samfunnsliv», "valget av ekteskapspartner må overlates helt til den som skal gifte seg» osv. Forskjellene er større mellom kjønnene enn den er mellom ungdom med og uten innvandrerbakgrunn, slik at jenter med innvandrerbakgrunn er mer i opposisjon til tradisjonelle holdninger på kjønnets område enn rent norske gutter er.

Mitt intervjumateriale gir langt på vei samme inntrykk som Øias undersøkelse gir. Blant de jentene jeg har intervjuet ser jeg tegn til at mange integrerer mange trekk fra norsk kvinnelighet i sine egne identiteter, og får det til på rimelig harmoniske måter. De legger vekt på utdanning, yrkeskarriere og på at deres egne døtre skal få større frihet enn de selv fikk. Men samtidig fremhever de fleste sitt opprinnelseslands familiekultur som noe positivt, og peker på større samhold og færre skilsmisser. Mange stiller seg også positive til arrangerte ekteskap, men understreker at det ikke må anvendes noen form for tvang. Hos guttene ser jeg ofte en tydelig avstand til fedregenerasjonen i en retning jeg anser som positiv. Her er flere som understreker husarbeid som felles ansvar og betydningen av kvinners yrkeskarrierer, her er flere som støtter søstrenes frigjøringsprosjekter og som erklærer seg som motstandere av den strenge seksualmoralen jentene pålegges. Holdningen til 
hjemlandets familietradisjoner er nok i hovedtrekk den samme som jentenes.

Men så finner jeg også noen svært tradisjonelle holdninger hos noen unge menn. I et tilfelle gjelder det en ytterst velintegrert gutt: Han ankom Norge først 13 år gammel, fra Pakistan, og jeg setter denne sene ankomsten i sammenheng med at han også på mange andre måter er langt mer knyttet til pakistanske tradisjoner enn de andre er, han er for eksempel den eneste som har en positiv holdning til det pakistanske kastesystemet. De tradisjonelle holdningene forhindrer ham imidlertid ikke i å utdanne seg til et typisk kvinneyrke, og heller ikke i å ha en kjæreste, selv om han vet det er galt i forhold til religionen.

Noen av de andre tilfellene av svært tradisjonelle holdninger gjelder noen av de mest marginaliserte blant de unge mennene Viggo Vestel og jeg har intervjuet, som Aman som vi møtte innledningsvis. Vi finner det også hos Mehmet, arbeidsløs drabantbygutt med tyrkiske foreldre og en litt småkriminell fortid. Han sier om norske jenter: "Selv om jeg er forelska i dem, det går ikke an å gifte deg med ... for det er kulturforskjell, ikke sant.» Han er ikke gift, men tenker altså at han skal gifte seg tyrkisk. "Jeg kan ikke godkjenne for eksempel når jeg gifter meg med en norsk kvinne at hun går på utesteder og vanker med andre gutter. Jeg godkjenner ikke masse annet hun gjør, jeg vil ikke at hun skal gå fri, ikke sant. Hvis hun skal gå på diskotek, hun kan gå sammen med meg.» Hun kan jobbe hvis hun vil: «Men det er jo egentlig mannfolk som jobber, og kvinnene, de skal være hjemme. Hvis hun vil jobbe, hun kan godt jobbe, men hvem skal passe ungene? Det er ikke jeg som skal passe på ungen når jeg skal jobbe, det går ikke. Jeg må passe på familien min, ikke sant, både kona mi og sønnen min.» Jeg synes det er ganske sterkt at han sier dette tatt i betraktning av at det er i Norge han har bodd siden han var 9 år gammel. At yrkesaktivitet og barnepass faktisk lar seg kombinere i de fleste norske fa- milier, takket være barnehager og dagmammaer, er noe han ikke engang tar i betraktning. Den samme Mehmet uttrykker sterke idealer for kameratskap mellom menn, knyttet til sterk lojalitet, til å stille opp for hverandre, og de voldsepisodene han har vært oppe i har ofte bakgrunn i disse idealene. Han mener også at vennskapet med andre som har utenlandsk bakgrunn er annerledes, og følelsesmessig tettere, enn vennskapet med norske: «Vi pleier å drikke for å fortelle om gamle dager, og bli mer venner, og fortelle om problemer. Vi har sånn problemtid og dansetid, ikke sant. Men med norske gutter og andre, jenter, når vi drakk sammen med dem, så hender det mange ganger at det blir bråk og tull og tøys. Men vi utlendingene, når vi drikker sammen, blir det aldri sånn, for vi prater mer om gamle tider og det blir mer sånn trøste hverandre.»

Tradisjonelle samfunns kjønnskomplementaritet handler ikke bare om store forskjeller i de to kjønns praksisformer, men også om tette bånd til andre av samme kjønn. Hos Mehmet og flere andre har jeg sett en tradisjonell innstilling til forholdet mellom kjønnene, en eiendomsholdning til jenter og en forakt for norsk kvinnelighet og mannlighet gå sammen med understreking av idealer om ære, respekt og sterk lojalitet i vennegjengen. Og akkurat disse trekkene kan vi finne igjen både i Liens og Haalands (1998) rapport og i Larsens (1992) bok, som begge har kriminelt belastede innvandrergutter fra drabantby- eller sentrumsmiljøer som sine hovedinformanter.

I mitt eget intervjumateriale finner jeg mange beretninger om slåsskamper i ungdomsårene, ofte knyttet til å skulle tøffe seg, noen ganger knyttet til ære og respekt, andre ganger knyttet til rasistiske provokasjoner eller til sjalusi. Men jeg blir slått av at de som forteller om motiverte slåsskamper, synes å ha svært korte lunter. Sjalusidramaer kan utløses av ingenting, en gutt sier han bare ikke tåler at noen ser på kjæresten 
hans. Han forteller om en episode han er flau over, da hadde den norske kjæresten danset med en venninne, så hadde en gutt på dansegulvet tatt på håret hennes. Da hadde han løpt ut på dansegulvet og skallet ned den gutten. Når han er flau over det, er det fordi han som ble skallet ned, viste seg å være en venn av venninnen, så han ble nødt til å be ham om unnskyldning. Det er klart det finnes mange sjalue norske gutter også, og mange avslappede innvandrergutter, og det er derfor meningsløst å si at denne voldsomme reaksjonen «skyldes» hans innvandrerbakgrunn. Men i Liens og Haalands (1998) studie av gjenger med betydelig innslag av innvandrergutter i Oslos østlige bydeler, vises det til at voldsepisoder svært ofte utløses av en opplevd krenkelse av en kjæreste, og at denne krenkelsen ofte synes å være av ubetydelig karakter. Men er denne holdningen til kjærestene sine noe de har med seg fra "sin kultur"? Ettersom de fleste av disse guttene, oftest av pakistansk, tyrkisk, iransk, marokkansk eller vietnamesisk opprinnelse, neppe ville hatt mulighet til å ha noen kjæreste i det hele tatt om de hadde vokst opp i sine foreldres hjemland, er det ikke derfra de henter sine scripts for hvordan man oppfører seg når man har en kjæreste. I sitt opprinnelsesland og fra sine fedre kunne de kanskje hente et script for hvordan man oppfører seg som ektemann, men det vil være nokså irrelevant. Det sier ingenting om hva man skal gjøre på et diskotek hvis en annen mann tar på konens hår, for en tar slett ikke konen med på diskotek. Kjæreste-scriptene er lokalt utviklet, og ganske sikkert resultater av en pregning fra høyst ulike kilder.

En annen og hyppig forekommende utløser av vold er rasistisk provokasjon. Et eksempel er en vietnamesisk gutt som har fått en voldsdom og som sier om det: «Det var på grunn av en rasistisk bemerkning. Han sa 'jævla guling', og jeg var ganske full så... da sa det pang. Jeg var på byen... jeg slo ham ned, og han lå nede ute for telling... så ble jeg tatt av politiet.» Episoden minner om flere andre beretninger jeg har hørt. Volden er slett ikke umotivert, men det virker som det skal nokså lite til for å utløse den. Og i dette tilfellet kan det ha sammenheng med at han driver med kampsport, og har opplevd at det har gitt ham større selvtillit. Han er en stor Bruce Lee-fan, og sier at den fremste grunnen til det er at Bruce Lee er orientalsk. Provokasjonen har en direkte sammenheng med hans innvandrerbakgrunn, reaksjonen hans har kanskje en indirekte sammenheng med denne innvandrerbakgrunnen, men også med en bestemt type ungdomskultur.

Temaer som ære, respekt og lojalitet dukker ofte opp i beskrivelser av voldsepisoder. Mehmet forteller at i et tilfelle hadde en annen gutt med tyrkisk bakgrunn fătt juling av en gutt av pakistansk opprinnelse, og da samlet 15 mann seg for å «banke dem», med køller, kjettinger, kniver og tåregassbomber. En person ble hardt skadet i oppgjøret. Mehmet sier: «Det var på grunn av kameraten min, for vi må hjelpe kameratene våre, ikke sant, hvis de blir slått ned. Hvis ikke, er det ikke bra kameratskap. Mange saker med politiet er på grunn av kameratene mine. Og jeg liker å hjelpe dem, jeg har aldri stukket fra dem.» Flere innvandrergutter mener selv at slike normer om å stille opp fysisk for sine kamerater står langt sterkere blant dem enn blant de rent norske.

Vi kjenner til gjengoppgjør som har endt i drap, som den saken Guri Larsen (1992) har analysert bakgrunnen for i boka Brødre. Hun skriver at hun i utgangspunktet ikke trodde på «kultur» som forklaring på drapet, men motvillig måtte gå med på at her handlet det nok litt om kultur likevel. I første omgang sier hun at det det handler om, er at ungdommene det gjelder er fristilte i forhold til kulturer. Neste stoppested for henne var å si at ungdommene så utviklet en motkultur, som reaksjon på den situasjonen de ble plassert i i det norske samfunnet. Men de involverte ungguttene protesterte mot hennes fortolkninger. For dem 
var deres bakgrunnskulturs verdier en viktig fortolkningsramme, og det handlet om ære og om lojalitet.

Men jeg stiller meg tvilende til at det er sine bestefedres æresforståelse de unge guttene med innvandrerbakgrunn prøver å etterleve når de snakker så mye om betydningen av xre og respekt. En av Larsens informanter, Juned, forteller nettopp om sin bestefar (Larsen 1992 s. 16): «Ære var viktig for bestefar. Han lærte meg at xren er en del av meg. Når jeg verdsetter meg selv, respekterer jeg andre, og når jeg ikke bryr meg om meg selv, kan jeg heller ikke respektere andre. Jeg tror også han mente at xre er å ta igjen hvis noen gjør familien noe vondt, for eksempel hvis de banker dem opp eller stjeler fra dem. Men, sa han, xre har ikke noe med religionen vår å gjøre. Ære har vi arvet fra dem som levde for mange tusen år siden. Men vi har bevart de gamle skikkene $\mathrm{i}$ islam. I islam er det tilgivelse, ikke hevn. Vi må tilgi, sa bestefar. Han lærte meg å være stolt over at jeg er muslim.» Æresidealet var altså ganske komplisert for bestefaren, det var knyttet til familien, men sto i motsetning til religionen. Sønnesønnen sitter i fengsel for drap på en med samme etniske bakgrunn som ham selv, men fra en annen gjeng. Fedrene hadde sett hvordan konfliktene mellom gjengene eskalerte, og arrangert et møte for å oppnå forsoning og tilgivelse. Hevnen er altså ikke fedregenerasjonens ideal. Men dagen etter en voldsepisode er Juned og hans venner ute etter nettopp hevn, på vegne av ham som ble skadet. Det er ikke noe slektskapsforhold mellom den som skal hevnes og de som gjør det, men de omtaler hverandre som brødre. Abubaker, som ble dømt for drapet sammen med Juned, sier (s.50): «De som ikke hjelper broren sin kan ikke hjelpe noen som helst i verden. De har ikke ære. De er ubrukelige. Vi er ikke ubrukelige. Vi tok hevn over vennen vår - broren vår som de andre hadde skadet. Deres måte å gjøre det på og vår måte skiller mellom hvem som er feig og hvem som har ære.» Forskjellen var at Juned og Abubaker var to mot en, og på den andres territorium, hvor han eventuelt kunne ha fått hjelp, mens de andre hadde vært tre mot en og på et nøytralt sted. Om dette gjør Abubaker til en mann av ære, er det en stor forskjell i hvordan Juneds bestefar og Abubaker snakker om ære, og det er i hvert fall meningsløst å snakke om en direkte, kulturell overlevering.

Vi har altså her sett at det kan være grunnlag for å hevde at det er noen særtrekk knyttet til maskulinitetsform i noen urbane miljøer med høyt innslag av gutter med innvandrerbakgrunn. Men disse særtrekkene kan ikke forklares med disse guttenes kulturelle bakgrunn.

\section{HAR NOEN SÆRLIGE MANNLIGHETS- IDEALER BETYDNING FOR DEN \\ KRIMINALITET NOEN UNGE \\ INNVANDRERMENN BEGÅR?}

Med dette som bakgrunn vil jeg nå nærme meg en avslutning og se på $\mathrm{i}$ hvilken forstand vi eventuelt kan tenke oss at noen spesielle, kulturelle eller subkulturelle trekk knyttet til maskulinitet har sammenheng med kriminalitet for noen gutter med innvandrerbakgrunn.

Om det finnes noen slik sammenheng, mener jeg det er galt å forstå den som et «kulturelt etterslep», som en pregning fra foreldregenerasjonen. Den nye generasjonen innvandrere er selvsagt preget av sine foreldre og sitt bakgrunnslands kultur. Men dette er en pregning som snarere beskytter mot å bli kriminelle enn den utsetter dem for å bli det, gjennom den sterke vekten på religion og på familiesamhold.

Jeg har tror det vi ser snarere skal forstås som noe nytt, i denne sammenheng at det er noen nye mannlighetsidealer som skapes, som er en sammensetning av mye forskjellig, en kreolisering. De unge med innvandrerbakgrunn skaper nye konstruksjoner, nye kulturelle trekk og nye identiteter ut fra en sammensatt og ny, sosial situasjon. Etni- 
sitet eller en etnisk identitet er ikke gitt en gang for alle, men skapes og gjenskapes i en vedvarende, sosial prosess (jfr. Bjurström 1997). En ung gutt i Norge med tyrkiske foreldre former ikke en «tyrkisk mannlighet», men en mannlighet som gutt i Norge med tyrkisk bakgrunn. Den særegne situasjonen kan lede mot en blandingsløsning. Men den kan også lede mot en forsterkning av det denne gutten oppfatter som utpreget tyrkisk, eller en rendyrking av det han oppfatter som norsk - eller kanskje til noe helt annet. For han skaper sin mannlighet ikke bare i sin familie eller ute blant norske, men også sammen med andre gutter som ofte kan ha ulik opprinnelse.

Dette er særlig tydelig i drabantbymiljøer, hvor disse konstruksjonene heller ikke lar seg avgrense til innvandrerguttene, men deles av mange av deres norske kamerater, i hvert fall et stykke på vei. Aman, som vi startet med, sier han har noen norske venner som har hengt med i samme gjeng $i$ noen år, og de sier at de ikke lenger kan være sammen med norske, at de ikke passer sammen med dem lenger, de har ikke noe å snakke om, og de synes ikke andre norske verdsetter vennskap nok. Norske foreldre på østkanten kan fortelle at de slås av at sønnene prater om respekt og slikt på en måte som er fremmed for dem. Journalist Tuva Gry Øyan siterer sin helnorske sønn (Dagsavisen Arbeiderbladet 18/1 1998): "'Det viktigste er æren', sier 16-åringen. 'Ære og respekt', gjentar han.» Hennes tolkning er at Oslos østlige bydeler er en smeltedigel hvor det vokser fram «en ny og mangeartet felleskultur, skapt av unge mennesker med familiebakgrunn fra Norge, $\mathrm{Pa}-$ kistan, Marokko, Vietnam og andre lande».

Jeg tror det som skjer er noe langt mer komplisert enn at noe pakistansk, noe marokkansk eller noe annet blandes med noe norsk. Her er ulike prosesser og mange slags impulser. Vi kjenner til fenomenet hvite niggere, fascinasjonen for gangsta'rap og ulike ord fra urdu og tyrkisk som blander seg inn i østkantslangen (dette studeres nå av Viggo Vestel i Oslo, se også Sernhede 1996a,b. De pakistanske guttenes begreper om ære og respekt er kanskje i mindre grad hentet fra deres bestefedres landsbykultur enn fra gangsterfilmer, fra hip-hop og rapmusikk, fra en svart, amerikansk kultur. Her er respect et nøkkelbegrep, sammen med attitude, tett knyttet til et maskulinitetsideal, som for $\varnothing v$ rig særpreges av lav toleranse for alle anslag mot denne respect'en. Det gjelder «å ikke miste ansikt». Samtidig ser vi i disse miljøene en sterk vekt på kroppslig kapital. Ikke bare uttrykt gjennom fysisk styrke, men også gjennom kroppsbeherskelse i forbindelse med dans og noen subkulturelle idretter, som skating og snowboard, og kampsporter hvor ferdigheter og styrke kombineres. Ove Sernhede (1996a) framhever at gangsterrappens stil handler om å være «bad», «hard» og «cool» (s.123). Her iscenesettes svart maskulinitet gjennom eksponering av veltrenede kropper, skytevåpen og sexistisk sjargong, og for mange hiphoppere er Mike Tyson et ideal - «det vita samhällets sinnebild för brutalitet, urkraft och hämningslös sexualitet» (s. 71). Hvordan ofte ganske puritansk innstilte, og i hvert fall temmelig bluferdige, muslimske gutter forholder seg til de seksuelle elementene i denne kulturen, fortjener en nærmere studie.

Disse nye ungdomskulturene inneholder mange elementer som nærmest kan ses som et slags kulturelt fellesgods for guttegjenger med arbeiderklassebakgrunn. En norsk gutt som har deltatt $\mathrm{i}$ en gjeng for noen år siden, kommenterer dagens gjenger, og sier de ikke følger samme regler for xre som i hans tid (Dagbladet 22/4 1998): "De sier de har ære, men de slår og voldtar jenter. Vi sloss for det vi sto for. Vi forsvarte vårt territorium, våre damer og våre ting». At xresbegrepet er tøyelig, og høyst åpent for lokale definisjoner, har vi allerede sett i uttalelsen fra Abubaker (Larsens informant, sitert ovenfor). Det er en del fellestrekk mellom dagens nasjonalitetsblandede guttegjenger, gårsdagens rent norske gutte- 
gjenger og de en møter i klassisk, kriminologisk litteratur. De har også en del fellestrekk med andre, samtidige guttegjenger, som MC-gjenger eller rockere, eller skinheads. Territorialitet, ære, kameratskap, fysisk tøffhet og en fetichering av mannskroppen går igjen. Symbolbruken skifter, men en del av innholdet er altså det samme, i hvert fall som idealer. Som nevnt er «ære» et tøyelig begrep, og eksempelet skinheads viser at også innholdet i begrepet om «samhold» eller «kameratskap» kan være ganske usikkert: Fangen (1998) viser at rivalisering, mistillit og baktaling er svært utbredt. Men idealet om «samhold» fungerer likevel som en samlende fane, og det er kanskje det som er idealenes viktigste funksjon, uavhengig av realitetene.

\section{ET LITE ETTERORD}

Innledningsvis gjorde jeg til kjenne et ubehag knyttet til at det er vanskelig å snakke om innvandrere og maskulinitet uten å kile utbredte fordommer. Her er også et annet ubehag, $\mathrm{i}$ at det under interessen for spørsmålet ligger et uuttalt syn på disse unge mennene som et problem - for det norske samfunnet. Det er jo ikke akkurat innvandrernes maskulinitetsformer vi trekker fram i festtalene om kulturelt mangfold som en berikelse for det norske samfunnet (selv om mange norske tenåringsjenter har sans for dem - til sine foreldres fortvilelse, men det var kanskje også meningen). Som en liten justering av dette ubehaget vil jeg minne om at i den grad innvandrernes maskulinitetsformer representerer et problem, så er det sannelig først og fremst for innvandrerkvinner. Det dreier seg om unge menn som skuffer sine mødre og gjør seg til uegnede ekteskapskandidater for jevnaldrende jenter. I noen tilfeller dreier det seg om menn som prøver å utøve en sterk kontroll over kvinner. En tyrkisk jente forteller om streng kontroll gjennom hele barndommen, så flyttet foreldrene tilbake til Tyrkia, men det ble ikke noe friere av det, for da var det storebror som tok over. Deretter ble hun giftet med en mann som kom rett fra landsbyen, og han var enda strengere, og påla henne å bruke bukser under kjolen, og nektet henne å gå ut med sine kolleger. Flere tyrkiske jenter forteller om en sterk sosial kontroll i form av at alle slags normbrudd kan bli sett av noen tyrkere, som så sørger for at foreldrene deres eller noen andre familiemedlemmer făr vite om det. Her er det altså en tradisjonell landsbykulturs sosiale kontroll av kvinner som videreføres i Norge.

Men det kan også handle om nye måter å være mann på som skaper problemer. For eksempel for vietnamesiske Zoun, som i hele oppveksten måtte arbeide så meget hjemme at hun elsket å gå på skolen - for å ha 'fri'. Hennes far er en hustyrann som spiller bort pengene han tjener. Hennes eldre bror går arbeidsløs og hennes mor er hjemmeværende, med to mindre barn. I dag er det Zoun, 21 år gammel og $\mathrm{i}$ et underbetalt kvinneyrke, som forsørger hele denne familien, i tillegg til at hun må ta seg av de yngre søsknene når hun kommer hjem fra arbeidet. "Jeg er en slave for familien min,» sier Zoun selv. Det som har skjedd henne handler verken om å leve i den opprinnelige kulturen eller om å gå inn i det norske. For den rollen Zoun har fătt er antakelig like atypisk for en vietnamesisk jente i Vietnam som for en norsk jente i Norge, og verken hennes far eller hennes bror lever slik de ville ha gjort i Vietnam. Det som har skjedd dem er noe nytt, som er et frambrakt av innvandringssituasjonen. Å peke på framveksten av slike nye livsformer og kulturelle uttrykk har vært et hovedsiktemål med denne artikkelen.

Takk til Olve Krange, Viggo Vestel og mine øvrige kolleger i ungdomsforskningsgruppen ved NOVA, samt til Anja Bredal ved ISF. 


\section{LITTERATUR}

. Bjurström, Erling (1997): The struggle for ethnicity - Swedish youth styles and the construction of ethnic identities. Young årg. 5 nr. 3.

- Bourdieu, Pierre (1979): La Distinction. Critique sociale du jugement. Ed. de Minuit, Paris.

- Bourdieu, Pierre (1995): Distinksjonen. En sosiologisk kritikk av dommekraften. Pax, Oslo.

- Bourdieu, Pierre og Loïc J.D. Wacquant (1993): Den kritiske ettertanke. Grunnlag for samfunnsanalyse. Samlaget, Oslo.

- Bourdieu, Pierre et.al. (1993): La misère du monde. Ed. du Seuil, Paris.

- Bourdieu, Pierre (1997): Méditations pascaliennes. Seuil, Paris.

- Dagbladet 22. april 1998: Tenåringer i rått mafiamiljø av Liz Buer.

- Fangen, Katrine (1998): A Death Mask of Masculinity. The Brotherhood of Norwegian RightWing Skinheads. I S. Evrø og T. Johansson (red.): Images of Masculinities: Moulding Masculinities. Ashgate Publ., Hants.

- Larsen, Guri (1992): Brødre. Areskamp og hjemloshet blant innvandringens ungdom. Pax, Oslo. - Lien, Inger-Lise og Thomas Haaland (1983): Vold og gjengatferd. En pilotstudie av et ungdomsmiljø. NIBR/Ungdom mot vold, Samarbeidsrapport.

- Mauger, Gérard og Claude Fossé-Poliak (1983): Les loubards. Actes de la recherche en sciences sociales $\mathrm{nr} .50$.

- Prieur, Annick (1998): Forholdet mellom kjønn og klasse med utgangspunkt i Bourdieus sosiologi. Sosiologisk tidsskrift, nr. 1-2.

- Sernhede, Ove (1996a): Ungdomskulturen och de Andra. Sex essäer om ungdom, identitet og modernitet. Daidalos, Gøteborg.

- Sernhede, Ove (1996b): Det fremmede - fascination og rædsel. Social kritik nr. 45-46.

- Wacquant, Loïc (1992): The Social Logic of Boxing in Black Chicago: Toward a Sociology of Pugilism. Sociology of Sport Journal, årg. 9.
- Wacquant, Loïc (1995): Pugs at Work: Bodily Capital and Bodily Labour Among Professional Boxers. Body \& Society, årg. 1, nr. 1.

- Øia, Tormod (1998): Generasjonskløften som ble borte. Ungdom, innvandrere og kultur. Cappelen Akademisk Forlag, Oslo.

- Øyan, Tuva Gry (1998): Det nye Norge. En urban, maskulin og multinasjonal ungdomskultur. Dagsavisen Arbeiderbladet 18/1.

\begin{abstract}
Considerable differences regarding gender relations exist between the native Norwegian population and immigrants. The article raises the question whether such differences may influence criminal acts commited by some young, male immigrants. Based upon a discussion of the difficulties of a cultural explanation, the author argues that these young men's attitudes and practices regarding gender performance and relations cannot be seen as deriving from their parents, but should be understood as a new response to a new and complex situation. Stressing honour, comradeship and the male body as a force, these new subcultural expressions have much in common with other male working-class cultures, and may be as influenced by contemporary American youth cultures as by Pakistani or Turkish village cultures.
\end{abstract}

Annick Prieur er dr. polit. i sosiologi og lektor ved Norsk institutt for forskning om oppvekst, velferd og aldring i Oslo. 